\title{
Role of Copper Sulphate on Oxidative and Metabolic Enzymes of Freshwater Fish; Channa Punctatus
}

\author{
Dharam Singh ${ }^{1 *}$, Shashwat Katiyar ${ }^{2}$ and Anju Verma ${ }^{1}$
}

${ }^{1}$ Department of Environmental Sciences, Institute of Bioscience \& Biotechnology, C S J M University, Kanpur - 208024

${ }^{2}$ Department of Biochemistry, Institute of Bioscience \& Biotechnology, C S J M University, Kanpur - 208024

\begin{abstract}
The effect of copper sulphate on liver, gills and kidney of fish Channa punctatus was observed as metabolic indicators. The fish were exposed to sub-lethal $\left(0.36 \mathrm{mg} \mathrm{l}^{-1}\right)$ concentrations for 15,30 and 45 days. The observations revealed that in the presence of copper sulphate the metabolic enzymes aspirate amino transferases (ASAT) and alanine amino transferases (ALAT) can enhance their activity, while catalase activity significantly reduced in response to elevated level of superoxide production in exposed fish as compared to healthy subjects. The major effect of copper sulphate toxicity on exposed fish shows as reduced amount of protein content as compared to unexposed fish. However, ASAT level have a significant negative correlation between catalase activity $(r=0.833, t=6.3872, p 0.05)$ and protein content $(r=0.8916, t=8.3540, p 0.05)$ in the exposed organs. These findings suggest that the significant increase of transaminase activity while reduced amount of catalase and protein content might be the consequences of tissue damage in Channa Punctatus.
\end{abstract}

Keywords: Metal pollution; Fish; Organs; Enzymes; Tissue damage

\section{Introduction}

Present day heavy metal pollution has become global concern. The early detection of heavy metal ions, especially bioavalable metal ion, in the environment is very important to safeguard to human health. Copper is an essential trace metal in small quantity for several fish metabolic functions. Essentiality of copper arises from its specific incorporation into a variety of enzymes such as peroxidase, xanthine oxidase, invertase, glucose oxidase and protease papain and bromelain $[1,2]$ which play important roles in physiological processes (e.g. enzymes involved in cellular respiration, free radical defense, neurotransmitter function, connective tissue biosyntheses and other functions), as well as, proteins. Copper is used today a chemotherapeutic agent in aquaculture however, the increased level of copper in aquatic environments coming from sewage, industries (electroplating, mining and metallurgy) and agricultural wastes [3,4]. Metals can either increase or decrease hepatic enzyme activities and can lead to histo-pathological hepatic changes, depending on the metal concentration, fish species, and length of exposure period [5]. Transaminase enzymes play vital role in carbohydrate-protein metabolism in fish tissues [6]. Changes in enzymes activity and other biomarkers have been studied as possible tools for aquatic toxicological research [7].

Increasing population, industrialization and agricultural production has resulted in increasing the number of freshwater systems which are being impaired by the contaminants present in wastewater releases $[8,9]$. Micronutrient interact with toxic metals at several points in body, absorption and excretion of toxic metals, transport of metals in body, binding to target proteins, metabolism and sequestration of toxic metals, and finally in secondary mechanisms of toxicity such as oxidative stress. Copper speciation is directly affected by water $\mathrm{pH}$, and the free cupric ion concentration is higher in water with low $\mathrm{pH}$, while a copper hydroxide complex prevails in water with high $\mathrm{pH}[10,11]$.

The aim of present study was to evaluate effect on metabolic indicators by sub-acute concentration of copper sulphate to a freshwater fish, Channa punctatus. The effects on organ were assessed by ALAT, ASAT, CAT and protein content.

\section{Materials and Methods}

\section{Experimental groups}

The metabolic indicator effect of copper was studied by static bioassay using tap water (University water supply) as dilution medium was estimated by the method of APHA [12]. The changes in physicochemical characteristics, such as temperature, $\mathrm{pH}$, TDS (total dissolved solids), DO (dissolved oxygen), hardness, alkalinity, chloride and iron of experimental water were recorded throughout the experimental period. The small size freshwater fish, Channa punctatus, weighing $15 \pm 2 \mathrm{~g}$ and measuring $11 \pm 2 \mathrm{~cm}$, were collected with the help of local fisherman from water bodies located in the sub-region of Lucknow. The fish was properly washed in tap water and treated with $0.02 \%$ $\mathrm{KMNO}_{4}$ and $0.004 \%$ formalin solution to remove external infection of fungi and algae. Prior to the experimentation the normal uninfected healthy fishes were selected for experiment. The fish were acclimatized to laboratory conditions 15 days before taken for experimentation. The animals were fed fish (TOKYO) made in Japan on each day in the evening. The $\mathrm{LC}_{50}$ was estimated employing Trimmed Spearman Karber Method [13] as $3.60 \mathrm{mg} \mathrm{l}^{-1}$. The sub-lethal dose $\left(0.36 \mathrm{mg} \mathrm{l}^{-1}\right)$ was related for exposure to fish for 15, 30 and 45 days.

\section{Design of sub-lethal toxicity study}

The fishes were divided into 4 equal groups consisting of 10 each and each group was transferred separately to glass aquaria of $100 \mathrm{~L}$ volume. While the Group I fishes were maintained as control without any treatment, the Group II, III and IV fishes were exposed to sub-

${ }^{*}$ Corresponding author: Dharam Singh, Department of Environmental Sciences Institute of Bioscience and Biotechnology, C S J M University, Kanpur (UP), India-208024, E-mail: ds_envi@rediffmail.com

Received November 13, 2011; Accepted January 03, 2012; Published January 05, 2012

Citation: Singh D, Katiyar S, Verma A (2012) Role of Copper Sulphate on Oxidative and Metabolic Enzymes of Freshwater Fish; Channa Punctatus. J Environment Analytic Toxicol 2:121. doi:10.4172/2161-0525.1000121

Copyright: () 2012 Singh D, et al. This is an open-access article distributed under the terms of the Creative Commons Attribution License, which permits unrestricted use, distribution, and reproduction in any medium, provided the original author and source are credited. 
lethal concentration $\left(0.36 \mathrm{mg} \mathrm{l}^{-1}\right)$ of copper sulphate for 15,30 and 45 days. The waste products were removed from aquaria water by using good quality of aquaria water filter. The solution of $\mathrm{CuSO}_{4} \cdot 5 \mathrm{H}_{2} \mathrm{O}$ (MERCK India) was freshly prepared distilled water before mixing in aquaria water. At the end of the exposure period i.e. 15, 30 and 45 days, the control and treated fish were killed and tissues collected for biochemical studies.

\section{Biochemical analysis}

The fish tissues liver, gills and kidney taken out were homogenized for the estimation of aspirate amino transferases (ASAT) and alanine amino transferases (ALAT) method of Reitman and Frankel [14] using a kit procured from Span Diagnostics (Surat, Gujrat), catalase by the method of Euller and Jopshon [15] and protein by the method of Lowry et al [16].

\section{Statistical analysis}

The data observed in the experiment were statistically analyzed for the calculation of standard error of mean (SEM). One way ANOVA and Duncan Multiple range test for individual group wise comparison was administrated for testing the hypothesis [17]. The data shown are the average of three replicates \pm SEM and statistical significance was tested at $\mathrm{p}<0.05$ level.

\section{Results}

Toxicity of copper sulphate on enzyme activity and protein content of exposed fish

The present study has revealed alteration in aspirate amino transferases (ASAT), alanine amino transferases (ALAT), catalase activity and protein content of treated fish (Figure 1-4). ASAT and ALAT activity progressively significant $(\mathrm{p}<0.05)$ increased with increase copper exposure period 15, 30 and 45 days as compared to control, respectively. ASAT activity was highly found on 45 days of kidney in comparison to treated group of liver and gills organs in fish (Figure 1), while ALAT activity was highly shows in liver and kidney on 45 days of exposed to copper in comparison to gills organs of Channa punctatus (Figure 2).

The result clearly indicated catalase activity in liver, gills and kidney were found reduced on 15, 30 and 45 days of exposed fish. Catalase activity was significantly $(\mathrm{p}<0.05)$ reduced in gills and kidney on 45 days in comparison to treated group of liver in fish, however 15 and 30 days of copper exposure period catalase activity was nearly found

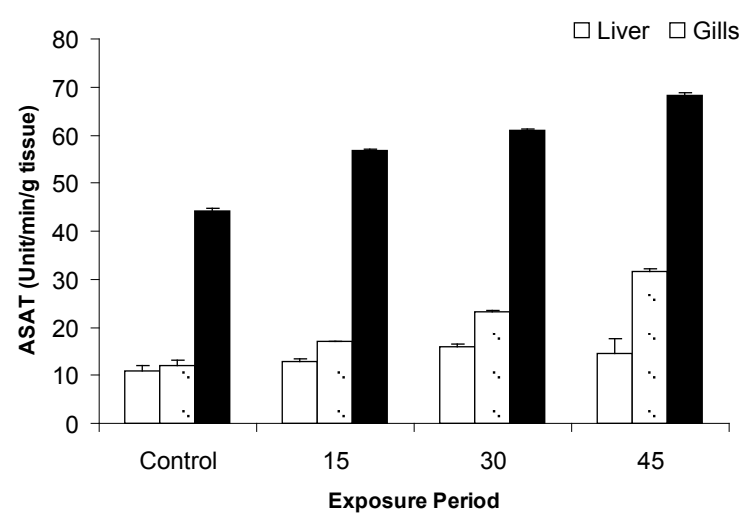

Figure 1: LEffect of copper sulphate on ASAT enzyme activity of fish at different exposure periods. Each value is mean (SEM) three replicates at $p<0.05$.

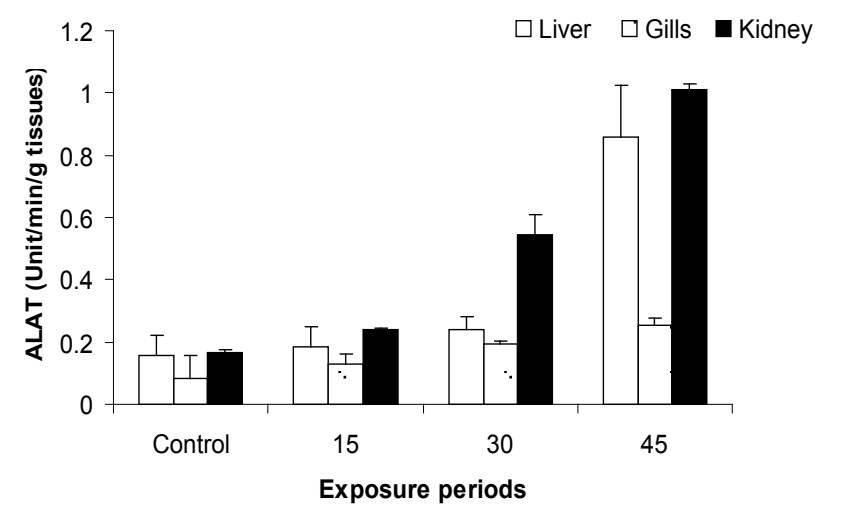

Figure 2: Effect of copper sulphate on ALAT enzyme activity of fish at different exposure periods. Each value is mean (SEM) three replicates at $p<0.05$.

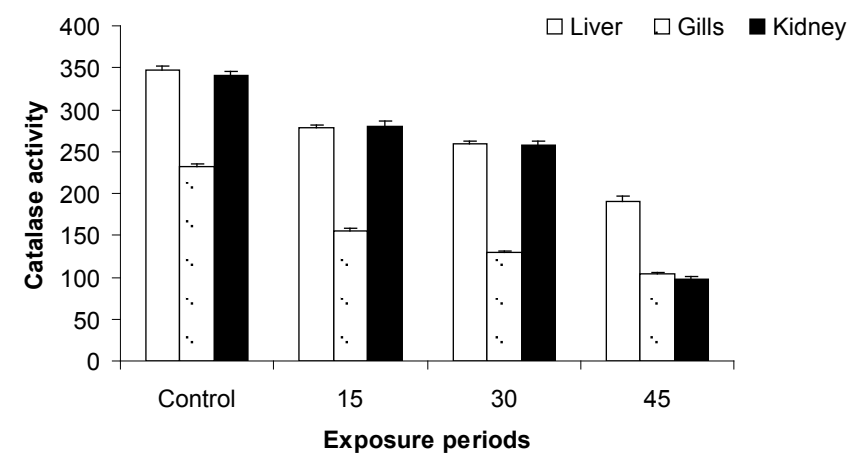

Figure 3: Effect of copper sulphate on catalase activity ( $\mathrm{ml} \mathrm{H} 2 \mathrm{O} 2$ hydrolyzed) of fish at different exposure periods. Each value is mean (SEM) three replicates at $p<0.05$.

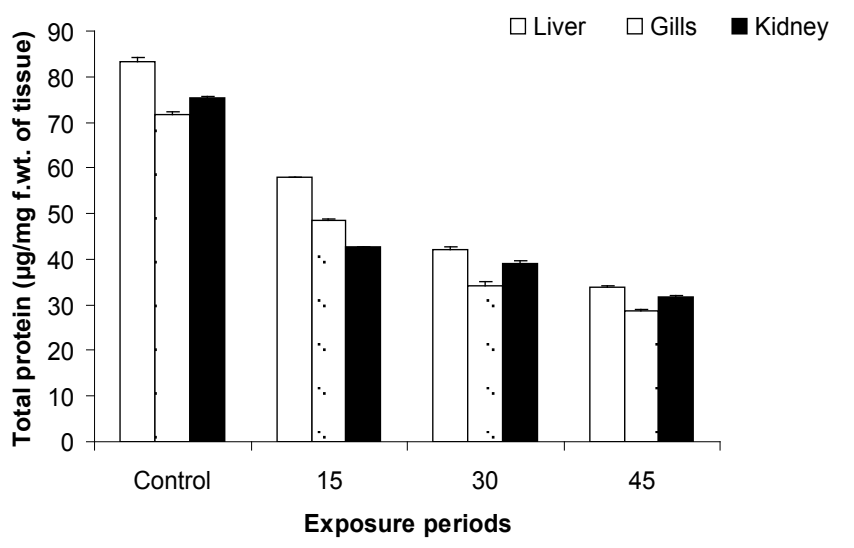

Figure 4: Effect of copper sulphate on total protein content of fish at different exposure periods. Each value is mean (SEM) three replicates at $p<0.05$.

in treated group of liver and kidney in fish, respectively (Figure 3). Protein contents in liver, gills and kidney were found significantly $(\mathrm{p}<0.05)$ reduced on 15,30 and 45 days of copper exposure period in comparison to control, respectively (Figure 4).

Significant negative correlation of asat with both catalase and protein content of copper sulphate exposed organs

ASAT have significant $(\mathrm{p}<0.05)$ negative correlation between 

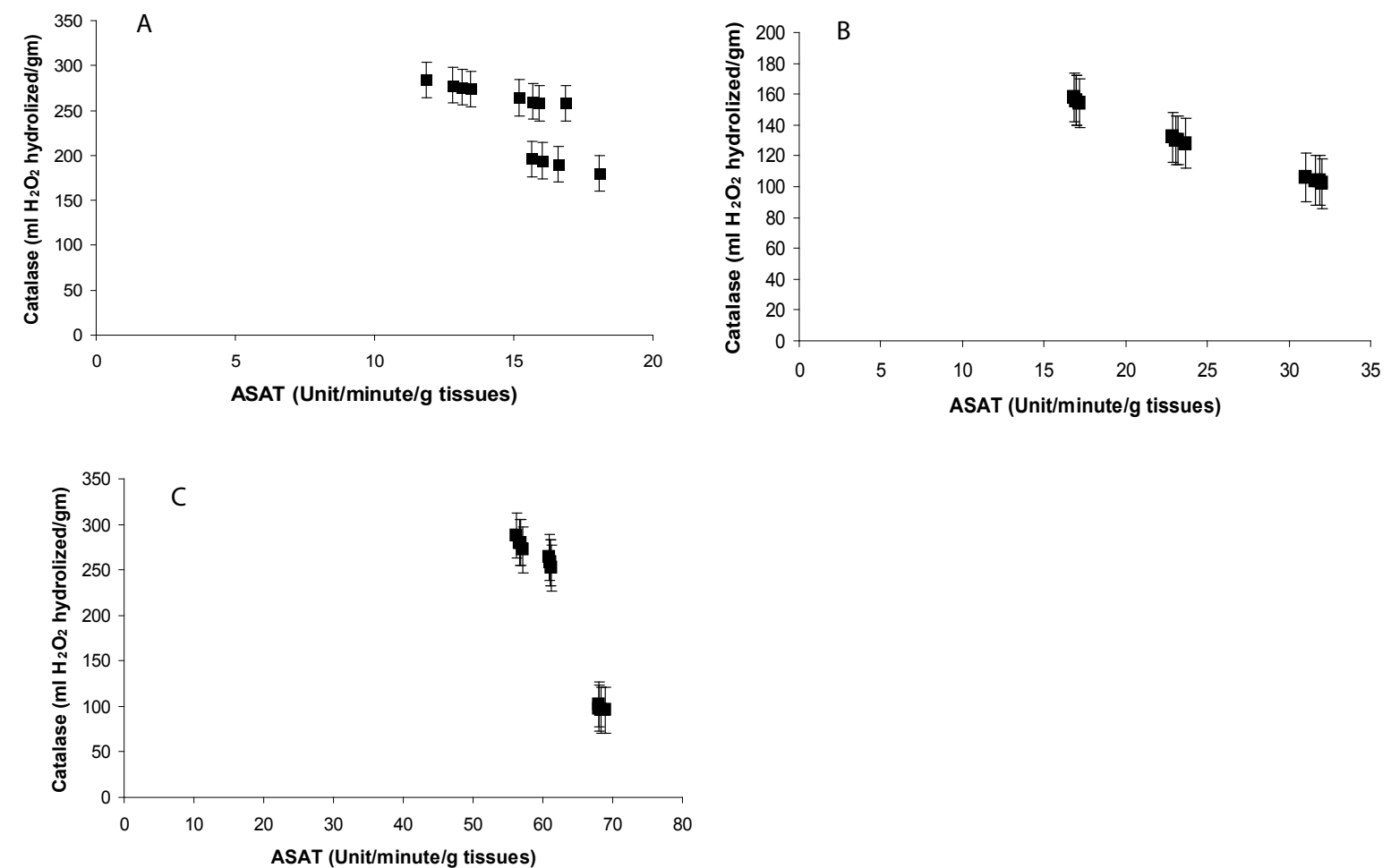

Figure 5: Correlation coefficient analysis for exposed fish organs. A significant negative correlation observed between ASAT and Catalase activity. a) Liver ( $r=$ $-0.7483, t=3.67, p<0.05)$, b) Gills $(r=-0.995, t=31.75, p<0.05), c)$ Kidney $(r=-0.963, t=11.30, p<0.05)$.
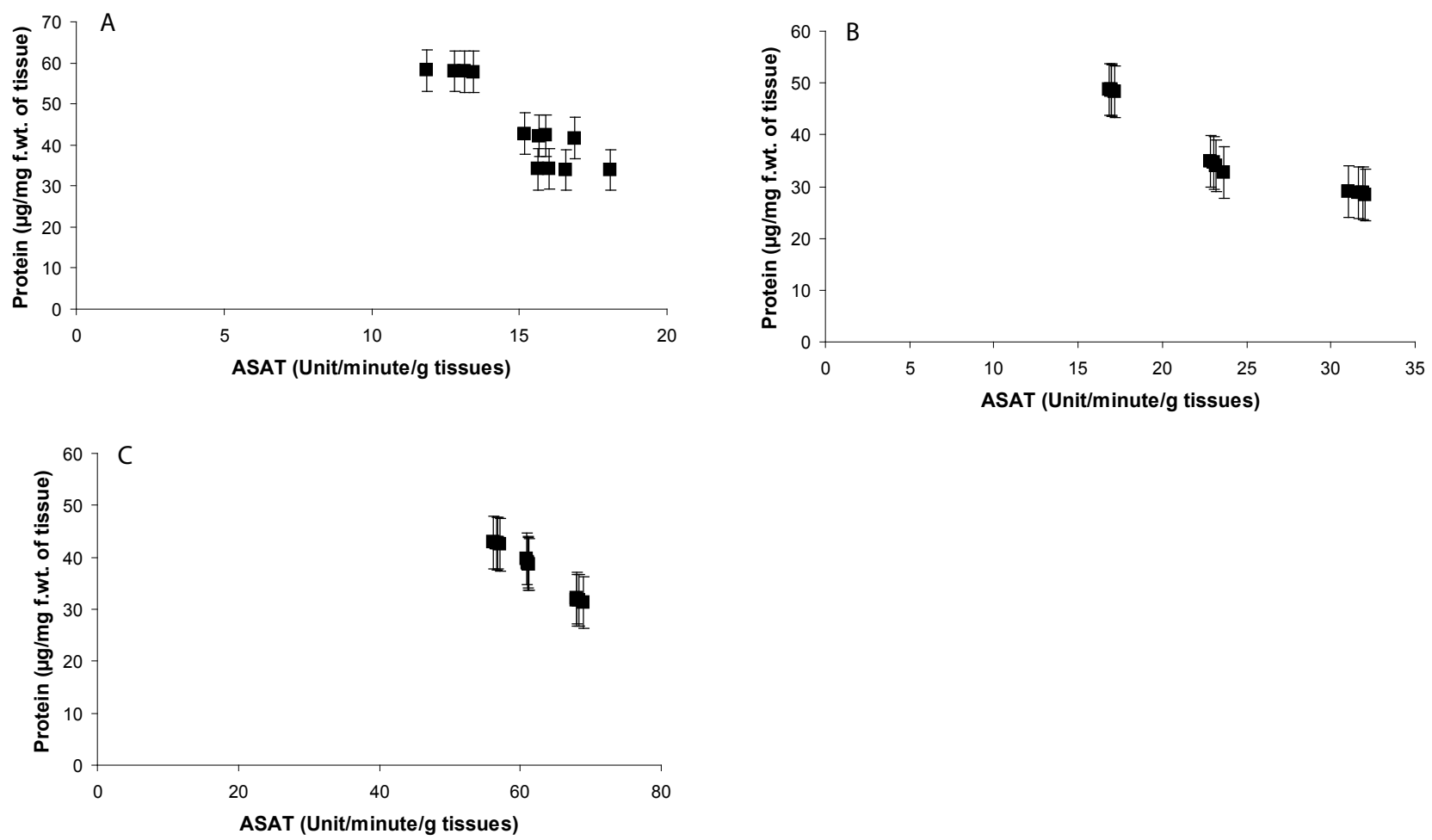

Figure 6: The correlation coefficient between ASAT and protein content in different organelles of copper sulphate exposed fish. a) Liver $(r=-0.906, t=6.765, p<0.05)$, b) Gills $(r=-0.939, t=8.650, p<0.05)$, c) Kidney $(r=-0.967, t=4.091, p<0.05)$. 
catalase and protein content of all the exposed organs of fish. The ASAT level of fish liver has significant negative correlation with catalase $(\mathrm{r}=-0.7483, \mathrm{t}=3.67, \mathrm{p}<0.05)$ and protein content $(\mathrm{r}=-0.906$, $\mathrm{t}=6.765, \mathrm{p}<0.05)($ Figure 5a-5c). Although a negative correlation observed between level of ALAT with catalase and protein content but it was not significant. Both gills and kidney of exposed fish shows highly significant negative correlation for observed value of ASAT with catalase and protein content (Figure 6a-6c).

\section{Discussion}

Fish prefers optimal environmental conditions for their growth and reproduction. Any change in environmental conditions causes stress on fish health. To maintain productivity of the ecosystem, a healthy aquatic environment and production of sufficient fish food organisms in water body is necessary. The liver, gills and kidney enzymes were unexpected since organs damage is indicated by an inhibition of these enzymes took place or a change in the metabolism of the fish. The metals have adverse effect on enzyme activity of fresh water fishes $[7,18,19]$. The fish developed a protective defense against the deleterious effect of essential and nonessential metals and other xenobiotics that produced degenerative changes like oxidative stress in the fish body [7,20,21]. The result of the present study shows reduced level of protein in liver, gills and kidney similar to the observation recorded by Mastan [22], Kumar and Gopal [23] on depletion level of protein in different organs of fish C. punctatus under the stress of copper and distillery effluents. Dinodia et al. [24] also carried out effect of cadmium toxicity on fresh water species Labeo rohita, Cirrhinus mrigala and Cyprinus carpio as evidenced by reduction in the body tissue and residual protein in all the fish species after 45 days of exposure, which may be due to dysfunction of several physiological and biochemical processes in the body.

Oxygen in its molecular state $\mathrm{O}_{2}$, is essential for many metabolic processes that are vital to aerobic life. Aerobic organisms cannot exist without oxygen, which nevertheless is inherently dangerous to their lives. Like all aerobic organisms, fish are also susceptible to the effects of reactive oxygen and have inherent and effective of different biotic and abiotic factors (age, phylogenetic position, feeding behavior, environmental factors, oxygen, temperature, presence of xenobiotics) on antioxidant defenses in fish [25]. The catalase activity decreased all organs with increases copper exposure period at 15, 30 and 45 days of exposure. Jee and Kang [26] also observed effect of phenanthrene exposure on Paralichthys olivaceus after 4 week incubation decreased catalase activity in the liver, gill and kidney tissues, however some study showed that there were no alteration catalase activity [27]. High concentrations of copper reduced catalase activity in the liver, gill and

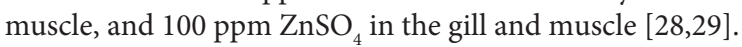

The activity of catalase decreased in liver of fish (Cyprinous carpio) in the Karakaya Dam Lake observed by Yilmaz et al. [30]. Ali et al. [31] observed similar result decreased catalase (CAT), activities liver and gills by fly ash leachate (FAL) exposued on Channa punctata. Buet et al. [32] Juvenile rainbow trout (Oncorhynchus mykiss) were carried out antioxidant enzymes like catalase were decreased in liver throughout the 10 days of uranium exposure. Copper Sulfate stimulation is potential biomarkers of exposure to an oxidative stress [33]. Trace metals, and high temperature, high salinity and light duration significantly decreased catalase activity of Mytilus galloprovincialis [34,35]. Santos et al. [36] the enzymatic and nonenzymatic antioxidants catalase, glutathione peroxidase, glutathione S-transferase and nonenzymatic antioxidant molecule such as glutathione in Anguilla anguilla L. gill, kidney and liver in decreased response to bleached kraft pulp mill effluent (BKPME). Pandey et al. [37] also observed catalase activity was inhibited in gills, liver and kidney of the freshwater fish Wallago attu (Bl. and Schn.). Asztolos et al. [38] observed increased lactate dehydrogenase (LDH), glutamic oxialoactetic trasmination (GOT) and glutamate dehydrogenase (GIDH) enzyme activity in Cyprinus carpio. Abdel Hameid [39] was observed assayed of enzyme alanine and aspartate amino transferases activity increase and protein contents was significantly reduced in fish Oreochromis aureus.

It is a fact that copper containg materials, capable of entering the body via the food chain, are harmful to the ecosystem. A way of analyzing these illnesses is to highlight the effects of these harmful chemicals on the enzymes. The changes in aspirate amino transferases (ASAT) and alanine amino transferases (ALAT), catalase and protein levels in gill, liver and kidney and following different exposure periods of sub-lethal copper concentration suggested that Channa punctatus showed adaptive elevation in the activity of enzymes in these tissues. These enzymes have a very important role in the metabolical process since they are biological catalysts. The enzymes could be successfully used as potential biomarker of fish health. Their deficiency or surplus indicates damage of body organs in fish. Intake of such type of food materials is very harmful to human beings.

\section{References}

1. Shukor MYB, Rahman NA Abdullah FA, Shamaan MP, Syed MA (2006) Development of heavy metals enzymatic based assay using papain. Anal Chem Acta 566: 283-289.

2. Shukor MY, Masdor N, Baharom NA, Jamal JA, Abdullah MP, et al. (2008) An inhibitive determination method for heavy metals using bromelain, a cysteine protease. Appl Biochem Biotechnol 144: 283-291.

3. Singh D, Nath K, Sharma YK, Trivedi SP (2008) Hepatotoxic effect of Cu(II) in freshwater fish Channa puntatus - A histopathological study. Res Environ Life Sci 1: 13-16.

4. Singh D, Nath K, Trivedi SP, Sharma YK (2008) Impact of copper on haematological profile of freshwater fish Channa puntatus. J Environ Biol 29 253-257.

5. Paris-Palacios S, Biagianti-Risbourg S, Vernet G (2000) Biochemical and (ultra) structural hepatic perturbation of Brachydanio rerio (Teleostei, Cyprinidae) exposed to two sublethal concentrations of copper sulphate. Aquat Toxicol 50 : 109-124.

6. Eze LC (1983) Isonlorid inhibition of liver glutamate oxaloacetic transaminase from goat Carpa hercus. Int J Biochem 15: 13-16.

7. Abou El-Naga EH, El- Moselhy KM, Hamed MA (2005) Toxicity of cadmium and copper and their effect on some biochemical parameter on marine fish Mugi seheli. Egyp J Aquat Res 31: 60-71.

8. Di Toro DM, Allen HE, Bergman HL, Meyer JS (2001) A biotic ligand mode of the acute toxicity of metals. I. Technical basis. Environ Toxicol Chem 20: 2383-2396.

9. Santore RC, Toro DMD, Paquin PR, Allen HE, Meyer JS (2001) A biotic ligand model of the acute toxicity of metals. II. Application to acute copper toxicity in freshwater fish and daphnia. Environ Toxicol Chem 20: 2397-2402.

10. Payle RC, Gensemer RW, Dixon DG (1992) Copper accumulation on gills of fathead minnows: Influence of water hardness, complexation and $\mathrm{pH}$ of the gill microenvironment. Environ Toxicol Chem 11: 381- 391

11. Tao S, Wen Y, Long A, Dawson R, Cao J, et al. (2001) Simulation of acid-base condition and copper speciation in fish gill microenvironment. Comp Chem 25 : 215-222.

12. APHA (2005) Standard methods for examination of water and waste water. $21^{\text {s }}$ Edition, Washington, D.C.

13. Hamilton MA, Russo RC, Thurston RV (1977) Trimmed Spearman-Karber Method for stimating median lethal concentrations in Toxicity Bioassays. Environ Sci Technol 11: 714-719.

14. Reitman S, Frankel S (1957) A calorimetric method for determination of serum glutamic oxaloacetic and glutamic pyruvic transaminase. Am J Cli Pathol 28 : $56-63$. 
Citation: Singh D, Katiyar S, Verma A (2012) Role of Copper Sulphate on Oxidative and Metabolic Enzymes of Freshwater Fish; Channa Punctatus. J Environment Analytic Toxicol 2:121. doi:10.4172/2161-0525.1000121

Page 5 of 5

15. Euller HV, Josephson K (1927) Uber Katalani I Liebigs Anon catalase activity. Annals of Botany 452: 158-184.

16. Lowry OH, Resebrough NJ, Farr AL, Randall RJ (1951) Protein determination with Folin reagent. J Biol Chem 193: 265-275.

17. Gomez KA, Gomez AA (1984) Statistical Procedure for Agricultural Research. John Wiley, New York.

18. Karan V, Vitorovic S, Tuundzic V, Poleksic (1998) Functional enzymes activity and gill histology of carp after coppr sulfate exposoure and recovery. Ecotoxicol Environ Saf 40: 49-55

19. Oner M, Alti G, Canli M (2009) Effect of metal (Ag Cd, Cr, Cu, Zn) exposures on some enzymatic and non-enzymatic indicators in the liver of Oohromis niloticus. Bull Environ Contam Toxicol 82: 317-321.

20. Filipovic V, Raspor B (2003) Metallothionein and meta levels in cytosol of river kidney and brain in relation to growth parameters of Mullus surmuletus and Liza aurata from the eastern Adriatic sea. Water Res 37: 3253-3262.

21. Farombi EO, Adelowo OA, Ajimoko YR (2007) Biomarkers of oxidative stress and heavy metals as indicators of environmental pollution in African cat fish Clarias gariepinus from Nigeria ogun river. Int $\mathrm{J}$ Environ Res Public Health 4: 158-165.

22. Mastan SA (2008) Copper induced change in protein level of certain tissues of Heteropneustes fossilis. J Herbal Toxicol 2: 33-34.

23. Kumar S, Gopal G (2001) Impact of distillery effluent an physiological onsequences in the fresh water teleost, Channa punctatus. Bull Environ Contom Toxicol 66: 616-622.

24. Dinodia GS, Jain KL, Gupta RK (2002) Effect of cadmium toxicity on total body carbohydrates and residual protein contents in some fresh water fishes. Himalayan J Environ Zool 16: 171-176.

25. Martinez-Alvarez, Rosa M, Amalia E, Morales, Ana Sanz (2005) Antioxidan defenses in fish: Biotic and abiotic factors. Rev Fish Biol Fish 15: 75-88.

26. Jee JH, Kang JC (2005) Biochemical changes of enzymatic defense system after phenanthrene exposure in olive flounder, Paralichthys olivaceus. Physiol Res 54: 585-591

27. Velma V, Tchounwou PB (2011) Hexavalent chromium induced multipal biomarker responses in liver and kideney of goldfish, Carassius auratus. Environ Toxicol 26: 649-656.
28. El-Seify MA, Zaki MS, Desouky ARY, Abbas HH, Abdel Hady OK, et al. (2011) Study on clinopthological and biochemical changes in some fresh water fishes infected with external parasites and subjected to heavy metal pollution in Egypt. Life Sci J 8: 401-405.

29. Radi AAR, Matkovices B (1988) Effects of metal ions on the antioxidant enzyme activities, protein content and lipid peroxidation of carp tissue. Comp Biochem Physiol 90: 69-72.

30. Yilmazi HR, Turkorz Y, Yuksel E, Orun I (2006) An investigation of antioxidant enzymes activities in liver of Cyprinus carpio taken from different stations in the Karakaya dam lake. Int J Sci Technol 1: 1-6.

31. Ali M, Parvez S, Pandey S, Atif F, Kaur M, et al. (2004) Fly ash leachate induces oxidative stress in freshwater fish Channa punctata (Bloch). Environ Int 30: 933-938.

32. Buet A, Barillet S, Camilleri V (2005) Changes in oxidative stress parameters in fish as response to direct uranium exposure. Radioprotection 40: 151-155.

33. Griffin BR, Davis KB, Schlenk D (1999) Effect of simulated copper sulfate therapy on stress indicators in channel catfish. J Aquat Animal Health 11: 231 236 .

34. Regoli F (1998) Trace metals and antioxidant enzymes in gills and digestive gland of the Mediterranean mussel Mytilus galloprovincialis. Earth Environ Sci 34: $48-63$

35. Khessiba, Asma, Michèle Roméo, Patricia Aissa (2005) Effects of some environmental parameters on catalase activity measured in the mussel (Mytilus galloprovincialis) exposed to lindane. Environ Pollut 133: 275-281.

36. Santos MA, Pacheco M, Ahmad I (2004) Anguilla anguilla L. antioxidants responses to in situ bleached kraft pulp mill effluent outlet exposure. Environ Int 30: 301-308.

37. Pandey, Suwarna, Suhel Parvez, Iqbal Sayeed et al. (2003) Biomarkers of oxidative stress: A comparative study of river Yamuna fish Wallago attu (BI. \& Schn.). Sci Total Environ 309: 105-115.

38. Asztalos J, Nemcsók I, Benedeczky R, Gabriel A, Szabó, Refaie OJ (1990) The effects of pesticides on some biochemical parameters of carp (Cyprinus carpio L). Arch Environ Contam Toxicol 19: 275-282

39. Abdel Hameid, NAH (2007) Physiological and histopathological alterations induced by phynol exposure in Oreochromis aureus juveniles. Turk J Fish Aquat Sci 7: 131-138 